\title{
A FEHÉR FAGYÖNGY (VISCUM ALBUM L.) ÁLTAL FERTŐZÖTT GAZDAFÁK DENDROMETRIAI TULAJDONSÁGAI KÖZÖTTI KAPCSOLATOK VIZSGÁLATA A FERTŐZÉS ERÖSSÉGÉNEK FÜGGVÉNYÉBEN
}

\author{
Baltazár Tivadar'1, Varga lldikó2 és Pejchal Miloš ${ }^{3}$ \\ ${ }^{1}$ Department of Agrochemistry, Soil Science, Microbiology and Plant Nutritions, Faculty of AgriSciences, \\ Mendel University in Brno \\ 2Enviroinvest Környezetvédelmi és Biotechnológiai Zrt. \\ ${ }^{3}$ Department of Planting Design and Maintenance, Faculty of Horticulture in Lednice, \\ Mendel University in Brno
}

\begin{abstract}
Kivonat
Jelen kutatás célja a fák magassága és a törzsátméröje közötti kapcsolat modellezése a gazdafajok és a fagyöngyfertőzés erősségének függvényében. Erre a célra 5 nemzetségböl (Acer, Crataegus, Juglans, Robinia és Tilia) összesen 10 gazdafajt választottunk ki, ami több mint 3000 (ebből fertőzött kb. 1400) egyedet jelent. A vizsgált gazdafajok a lednicei kastélyparkban találhatóak, ami a fagyöngy elterjedés egyik centruma Csehországban. A kapcsolat jellemzésére logaritmikus regressziót választottunk, ami viszonylag pontosan és egyszerüen modellezi e két dendrometriai tulajdonság közötti kapcsolatot. A kapott eredményekböl egyértelmüen megállapítható, hogy a fertőzés növekedésével egyenes arányosan csökken a famagasság és törzsátmérő közötti kapcsolat erőssége, a különbség több gazdafaj esetében is statisztikailag szignifikánsnak bizonyult. Mindazonáltal ennek a kapcsolatnak a pontos modellezése sokkal bonyolultabb, mivel a fagyöngy jelenlétének negatív hatása eltérö lehet akár gazdafajon belül is.
\end{abstract}

Kulcsszavak: fehér fagyöngy, Viscum album, fertőzés intenzitása, famagasság, törzsátmérö.

\section{INVESTIGATION OF RELATIONSHIP BETWEEN DENDROMETRIC VARIABLES OF INFECTED HOST TREES BY EUROPEAN MISTLETOE (VISCUM ALBUM L.) WITH DEPENDENCE OF INFECTION INTENSITY}

\begin{abstract}
The aim of our study was modeling the relationship between the tree height and diameter at breast height (DBH) with dependence of host taxa and mistletoe infection intensity. Ten woody species have been selected for this study from 5 genera (Acer, Crataegus, Juglans, Robinia and Tilia) representing more than 3,000 individuals whereof about 1400 are already infected. The examined host taxa can be found in the castle park of Lednice in Czech Republic. The park is in the centers of the mistletoe distribution in this region. Logarithmic regression was chosen characterizing this relationship because these two dendrometric variables relatively accurately and simply. From the obtained result, it can be clearly established that as the infection intensity increases, the relationship between the height and DBH decreases proportionally. The difference was also statistically significant for several other host species. However, the exact modelling of this relationship is more complicated, because the negative effect of mistletoe may differ within host species too.
\end{abstract}

Keywords: European mistletoe, Viscum album, infection intensity, tree height, diameter at breast height. 


\section{BEVEZETÉS}

A famagasság (tree height $-H$ ), illetve a törzsvastagság (diameter at breast height $D B H$ ) az egyik legfontosabb dendrometriai tulajdonság, ami a fakataszter összeállítása során rögzítésre kerül egy konkrét faegyed esetében (Kurz et al 1992, Sharma 2009). Ezek az alapadatok rendszerint nemcsak a további dendrometriai tulajdonságok meghatározásának alapját adják (pl. a famagasságból kiszámítható a korona térfogata), hanem adathiány esetében pl. egy adott faj törzsvastagságából is következtethetünk annak magasságára (Curtis et al 1981, Huang 1999). A faegyedek ezen (és egyéb kiegészitő) tulajdonságai segitheti feltérképezni egy adott erdei növénytársulás aktuális állapotát és fejlődését az idő függvényében (Huang \& Titus 1994, Moore et al 1996).

A kettő közül rendszerint a fa magasságának mérése nehezebb és időigényesebb, valamint nagyobb hibalehetőséget is von maga után, föleg akkor, ha a vizsgált faegyedek nem szoliterként, hanem összefüggő facsoportokban helyezkednek el (Huang et al 2000, Ahmadi et al 2013). Ebből kifolyólag egy nagyobb erdei fakataszter összeállitása során a törzsvastagságot minden faegyed esetében, míg a magasságot csak néhány faj esetében mérik (Peng et al 2001, Lumbers et al 2011). A törzsvastagság mérése esetén a fakéreg, illetve annak vastagsága torzíthatja a mérési eredményeket, de szélsőséges esetekben olyan technikai problémák is felmerülhetnek (pl. duplatörzs) ami megakadályozza a törzsvastagság mérésének $1,3 \mathrm{~m}$ magasan történő elvégzését (Colbert et al 2002, Pejchal 2008).

A famagasság és a törzsátmérő közötti kapcsolat jellemzése különböző matematikai modellek segítségével történik, amelyek többé-kevésbé követik a famagasság változását a törzsátmérő vastagságának függvényében (Botkin et al 1972, Vanclay 1994, Misir 2010). A vizsgálat elvégzésére számos matematikai modellt fejlesztettek $\mathrm{ki}$ - az egyszerüektől az egészen bonyolultabbig - melyek alkalmazása elsősorban a vizsgált fafajtól függ (Calama \& Montero 2004, Sharma \& Zhang 2004, Krisnawati et al 2010). E matematikai modell öszszeállitását nehezíti, hogy a magasság és a törzsátmérő közötti kapcsolat tipikusan nem lineáris, ami azzal magyarázható, hogy a faegyedek növekedési erélye az idő előrehaladtával fokozatosan csökken (Niklas 1995, Zhang 1997).

A famagasság és a törzsvastagság közötti kapcsolat elemzését tovább nehezíti az a tény, hogy a növekedést befolyásolhatják olyan tényezők is, amelyek hatását nem lehet pontosan elörevetíteni (Zuber 2004, Dobbertin et al 2005, Dobbertin \& Rigling 2006). Ezek közé nemcsak azok a faktorok tartoznak (pl. az adott régió klímája, tengerszint feletti magasság, talajípus stb.), aminek valószínüsítő hatásai az adott statisztikai modellbe viszonylag könynyen beépíthetök, hanem azok a tényezők is (pl. kórokozók és kártevők, fajon belüli eltérések stb.), amelyek hatása rendszerint erősen változó és eltérő akár országon vagy régión belül is (Kartoolinejad et al 2007, Kołodziejek et al, 2013). Ezen kívül elkülönítve kell kezelni azokat a faegyedeket, amelyek városi környezetben élnek, mivel ebben az esetben a növények eleve nagyobb stressznek vannak kitéve, mint a természetes környezetükben előfordulóak, ami kihatással van az adott fafaj növekedési erélyének csökkenésére is (Paganová 2008, Paganová \& Bakay 2010). 
A fehér fagyöngy (Viscum album L.) félélösködő révén számos olyan kárt tud okozni az általa fertőzött gazdafán, amelyek hatása rendszerint visszafordíthatatlan (Stopp 1961, Grundmann et al 2012). Ezek közül legfontosabb, hogy szignifikánsan csökkenti a gazdafaj magasságát és törzsátméröjét, bár nem egyértelmü, hogy a magasságcsökkenés közvetlenül a fagyöngy fertőző hatásától, vagy a faegyed csökkent életereje következtében közvetve következik be (Tubeuf 1923, Hawksworth 1983, Barbu 2012).

A fertőzöttség és a gazdafa dendrometriai tulajdonságai közötti kapcsolatot számos szerző vizsgálta (Noetzi et al 2003, Kanat et al 2010, Catal \& Carus 2011). A perzsa varázsfa (Parrotia persica (DC.) C. A. Mey.) és az ezüst juhar (Acer saccharinum L.) esetében statisztikailag szignifikáns (sok esetben pozitív) kapcsolatot jegyeztek fel a gazdafa magassága, illetve annak törzsátmérője és a fertőzöttség között. A famagasság és a gazdafa törzsvastagságának növekedésével növekszik a fertőzöttség, illetve a fertőzött fák rendszerint magasabbak (Kartoolinejad et al 2007, Kołodziejek \& Kołodziejek 2013, Kołodziejek et al 2013).

A jelen kutatás célja a famagasság és a törzsátmérő közötti kapcsolat modellezése a fagyöngyfertőzés erősségének függvényében. A fő cél olyan matematikai modell keresése, aminek segítségével nagy valószínüséggel meghatározható a gazdafa magassága, annak törzsátmérőjének és a fertőzés erőssége függvényében. Mindazonáltal feltételezzük, hogy a fertőzés erősségének növekedése következtében még gazdafajon belül sem írható le pontosan a famagasság és a törzsátmérő közötti kapcsolat szabályos matematikai modellekkel.

\section{ANYAG ÉS MÓDSZER}

A kutatásunk során vizsgált gazdafajok a Lednice község kastélyparkjából (Břeclav járás, Csehország) kerültek ki, ami a fagyöngy elöfordulásának egyik legnagyobb centruma, míg a potenciális gazdafajok számának tekintetében a legmagasabb az egész országban (Spálavský 2001, Procházka 2004, Bulií 2010). A mintaterület Csehország legmelegebb része (az évi átlaghőmérséklet $9{ }^{\circ} \mathrm{C}$ körüli), ami tovább kedvez a fagyöngy terjedésének (Skalický 1988, Culek 1996).

A kastélypark összterülete a halastavakkal együtt kishiján eléri a 200 ha-t. Az egész park területén nagy számmal találhatók fásszárú növények, amelyek egy része nagyobb faállományban, másik része kisebb facsoportokban, töredéke pedig szoliterként fordul elő. A fásszárú növények közel 20\%-a tülevelü, azonban a park területén kizárólag lombhullatók fajok fertőzöttek. A parkban előforduló taxonok száma 540 körül van, ami kb. 15000 faegyedet jelent (Spálavský 2001, Krejčiř́k et al 2015).

A vizsgálat során felhasználtuk nemcsak az eredeti fakatasztert, hanem annak frissített változatát is, ami a parkban található összes fásszárú egyedet tartalmazza (Pejchal \& Šimek 1996, Šimek et al 2003, 2009). A meglévő fakatasztert fokozatosan aktualizáltuk 2011 és 2013 között, amibe aztán a fagyöngyfertőzésre vonatkozó adatok is belekerültek. Minden egyes faj pontos meghatározásra került annak tudományos nevével (Erhardt \& Zander 
2008), amihez hozzárendeltük az alapvető dendrometriai tulajdonságaikat (Machovec 1982, Pejchal 2008, Pejchal \& Šimek 2015): famagasság (magasságmérővel, 1 m pontossággal mérve) és a törzsvastagság ( $1 \mathrm{~cm}$ pontossággal mérve $1,3 \mathrm{~m}$ magasságban a földfelszíntől).

A fagyöngy fertőzés megállapítása során egy arányt kerestünk az összfagyöngytérfogat és a lombkorona között, amit aztán százalékos formában fejeztük ki és az alábbi fagyöngyfertőzési skálát hoztunk létre (Spálavský (2001) alapján módositva):

0 . nem fertőzött: vizsgált faegyed nincs fagyönggyel fertőzve $(0 \%)$

1. kis mértékben fertőzött: a faegyed vagy egyetlen fagyöngybokorral fertőzött vagy többel, ebben az esetben az összfagyöngytérfogat nem haladja meg a lombkorona térfogat egy tizedét (1-10\%)

2. közepes mértékben fertőzött: a faegyed közepes mértékben fertőzött esetleg némely vázága nagyobb mértékben, azonban a fagyöngybokrok össztérfogata a lombkorona térfogatának maximum $40 \%$-a

3. erősen fertözött: a faegyed nagy mértékben fagyönggyel fertőzött (beleértve a fa összes vázágát, illetve az egyes ágvégeket is), a fagyöngybokrok össztérfogata már meghaladhatja a lombkorona térfogata felét is (41-100 \%)

Az adatelemzés során - pontosabb eredmények érdekében - kizárólag azokkal a gazdafajokkal dolgoztunk tovább, amelyek a leggyakrabban fordultak elő a kastélyparkban. Ebből kifolyólag összesen 10 gazdafajt használtuk fel (1. táblázat).

1. táblázat: A lednicei kastélypark leggyakoribb gazdafajai a fertőzés függvényében.

Table 1: The most common host species of Castle park Lednice depending on infection.

\begin{tabular}{|l|c|c|c|c|c|}
\hline Gazdafa & $\begin{array}{c}\text { Összesen } \\
(\mathbf{d b})\end{array}$ & $\begin{array}{c}\text { Nem } \\
\text { fertözöttt }\end{array}$ & $\begin{array}{c}\text { Kis } \\
\text { mértékben } \\
\text { fertözött }\end{array}$ & $\begin{array}{c}\text { Közepes } \\
\text { mértékben } \\
\text { fertözött }\end{array}$ & $\begin{array}{c}\text { Nagy } \\
\text { mértékben } \\
\text { fertözött }\end{array}$ \\
\hline Acer campestre L. & 1266 & 733 & 377 & 117 & 39 \\
\hline Acer platanoides L. & 159 & 66 & 68 & 14 & 11 \\
\hline Acer pseudoplatanus L. & 205 & 125 & 45 & 18 & 17 \\
\hline Crataegus spp. & 188 & 93 & 66 & 23 & 6 \\
\hline Juglans nigra L. & 117 & 34 & 17 & 35 & 31 \\
\hline Robinia pseudoacacia L. & 142 & 64 & 67 & 8 & 3 \\
\hline Tilia cordata Mill. & 515 & 222 & 94 & 94 & 105 \\
\hline Tilia platyphyllos Scop. & 447 & 277 & 107 & 30 & 33 \\
\hline Összesen (db) & $\mathbf{3 0 3 9}$ & $\mathbf{1 6 1 4}$ & $\mathbf{8 4 1}$ & $\mathbf{3 3 9}$ & $\mathbf{2 4 5}$ \\
\hline
\end{tabular}

A statisztikai elemzések során a famagasság és a törzsátmérő közötti kapcsolat jellemzésére - a fertőzés erősségének függvényében - variancia-kovariancia-elemzést (analysis of covariance - ANCOVA) alkalmaztunk, ami tulajdonképpen a hagyományos regresszió és a varianciaanalízis ötvözete. Ehhez folytonos függő változóként (continuous response variable) a famagasságot, kategoriális magyarázó változóként/faktorként (categorical explana- 
tory variable - factor) a fagyöngyfertőzés erősségét, valamint a törzsvastagságot, mint kovariáns (covariate) vettük figyelembe. Utóbbin logaritmikus transzformációt hajtottunk végre, hogy e kapcsolatot, mint lineárisra visszavezethető regressziót tudjuk kezelni. A regressziós egyenes együtthatóit a közönséges legkisebb négyzetek módszere (ordinary least squares method - OLS) szerint határoztuk meg. A két dendrometriai tulajdonság között kapcsolat erősségének meghatározása determinációs együttható (determination coefficient) segítségével történt. A teljes modell esetében pedig a szórásnégyzeteket F-próbával, a hatásméretet pedig a parciális éta négyzet (partial eta squared) segítségével határoztuk meg. Az elemzések elvégzése után minden esetben elvégeztük - különböző próbák és diagnosztikus ábrák segítségével - az adott statisztikai modellre vonatkozó feltételeket.

A gyüjtött adatok tárolását és feldolgozását a Microsoft Office Excel 365 táblázatkezelő program online verziójával, míg a bonyolultabb statisztikai elemzéseket pedig az $\mathbf{R}$ statisztikai program 3.6.1. verziójával végeztük ( $R$ Core Team 2019) az alábbi kiegészitő csomagok segítségével: „BaylorEdPsych” (Beaujean 2012), illetve a "ggplot2” (Wickham 2016) a haladó szintű grafikus ábrázoláshoz. A statisztikai elemzésekhez és az eredmények grafikus ábrázolásához szükséges $R$ szkriptum összeállításához pedig a Tinn-R kódszerkesztő programot (Faria et al 2013), illetve az eredményeket azonnal megjelenítő RStudio kiegészítő segédprogramot (RStudio Team 2015) együttesen használtuk fel.

\section{EREDMÉNYEK ÉS KÖVETKEZTETÉSEK}

A variancia-kovariancia elemzés eredményei alapján elmondható, hogy a fagyöngy hatása statisztikailag nem szignifikáns az alábbi gazdafajok esetében: Acer campestre $\left(\mathrm{F}_{3,1258}\right.$ $\left.=0.91, p=0.43, \eta_{p}^{2}=0.002\right)$, Acer platanoides $\left(F_{3,151}=2.48, p=0.06, \eta_{p}{ }^{2}=0.047\right)$, Acer pseudoplatanus $\left(F_{3,197}=1.48, p=0.22, \eta_{p}^{2}=0.02\right)$, Crataegus spp. $\left(F_{3,180}=1.92, p=0.13\right.$, $\left.\eta_{p}{ }^{2}=0.03\right)$, Juglans nigra $\left(F_{3,109}=1.17, p=0.32, \eta_{p}^{2}=0.03\right)$ és a Robinia pseudoacacia $\left(F_{3,134}=0.75, p=0.52, \eta_{p}{ }^{2}=0.016\right)$. A fagyöngy hatása azonban statisztikailag szignifikánsnak bizonyolult a Tilia cordata $\left(F_{3,507}=6.02, p<0.001, \eta_{p}^{2}=0.03\right)$ és a Tilia platyphyllos $\left(F_{3,439}=6.28, p<0.001, \eta_{p}^{2}=0.041\right)$ gazdafajok esetében.

A fagyöngy és a famagasság közötti interakciós kapcsolat vizsgálata esetében csupán az Acer campestre $\left(F_{3,1258}=5.22, p=0.001, \eta_{p}{ }^{2}=0.01\right)$ gazdafaj esetében találunk statisztikailag szignifikáns különbséget, a többi fajnál már azonban nem: Acer platanoides ( $\mathrm{F}_{3,151}=$ 2.14, $\left.p=0.10, \eta_{p}^{2}=0.04\right)$, Acer pseudoplatanus $\left(F_{3,197}=2.40, p=0.07, \eta_{p}^{2}=0.04\right)$, Crataegus spp. $\left(F_{3,180}=1.10, p=0.35, \eta_{p}^{2}=0.02\right)$, Juglans nigra $\left(F_{3,109}=1.57, p=0.20, \eta_{p}{ }^{2}\right.$ $=0.04)$ Robinia pseudoacacia $\left(\mathrm{F}_{3,134}=1.29, \mathrm{p}=0.28, \eta_{\mathrm{p}}{ }^{2}=0.028\right)$, Tilia cordata $\left(\mathrm{F}_{3,507}=\right.$ 1.99, $\left.p=0.11, \eta_{p}{ }^{2}=0.01\right)$ és a Tilia platyphyllos $\left(F_{3,439}=0.60, p=0.62, \eta_{p}^{2}=0.004\right)$.

A variancia-kovariancia elemzés eredményei továbbá bebizonyították a logaritmikus kapcsolatot a famagasság és a törzsátmérö között, ami az összes gazdafaj esetében statisztikailag szignifikáns: 
- $\quad$ Acer campestre $\left(F_{7,1258}=159.9, p<0.001 ; R^{2}=0.47\right.$, adj. $\left.R^{2}=0.47\right)$,

- Acer platanoides $\left(F_{7,151}=19.55, p<0.001 ; R^{2}=0.48\right.$, adj. $\left.R^{2}=0.45\right)$,

- $\quad$ Acer pseudoplatanus $\left(F_{7,197}=39.16, p<0.001 ; R^{2}=0.58\right.$, adj. $\left.R^{2}=0.57\right)$,

- Crataegus spp. $\left(F_{7,180}=20,13, p<0.001 ; R^{2}=0.44\right.$, adj. $\left.R^{2}=0.42\right)$,

- Juglans nigra $\left(F_{7,109}=14.81, p<0.001 ; R^{2}=0.49\right.$, adj. $\left.R^{2}=0.45\right)$,

- $\quad$ Robinia pseudoacacia $\left(F_{7,134}=21.99, p<0.001 ; R^{2}=0.53\right.$, adj. $\left.R^{2}=0.51\right)$,

- Tilia cordata $\left(F_{7,507}=87.52, p<0.001 ; R^{2}=0.55\right.$, adj. $\left.R^{2}=0.54\right)$,

- Tilia platyphyllos $\left(F_{7,439}=83.31, p<0.001 ; R^{2}=0.57\right.$, adj. $\left.R^{2}=0.56\right)$.

A 2. táblázat mutatja a regressziós koefficiensek alakulását a fagyöngyfertőzés erősségének függvényében a leggyakoribb gazdafajok esetében. Az elemzés során logaritmikus regressziót alkalmaztunk, ahol a törzsvastagságon hajtottuk végre a logaritmikus transzformációt. Az első szám (intercept) az y tengellyel való metszéspont, a második szám a regressziós egyenes meredekségét (slope) határozza meg. A regressziós egyenesen kívül minden esetben feltüntettük a determinációs együtthatót is.

2. táblázat: $A$ famagasság $(H)$ és a törzsátmérő $(D B H)$ közötti kapcsolat alakulása különböző gazdafajok esetében a fagyöngyfertőzés függvényében.

Table 2: Development of the relationship between tree height $(H)$ and diameter at breast height (DBH) in case of host taxa with dependence of mistletoe infection.

\begin{tabular}{|c|c|c|c|}
\hline \multirow{4}{*}{ Gazdafa } & A fertözés erössége & Regressziós függvény & $\begin{array}{c}\text { Determinációs } \\
\text { együttható } \\
\left(\mathbf{R}^{2}\right)\end{array}$ \\
\hline \multirow{4}{*}{$\begin{array}{c}\text { Acer } \\
\text { campestre }\end{array}$} & nem fertözött (0.) & $\mathrm{H}=-6.33+5.85^{*} \log (\mathrm{DBH})$ & 0.48 \\
\cline { 2 - 4 } & kis mértékben (1.) & $\mathrm{H}=-2.84+4.80^{*} \log (\mathrm{DBH})$ & 0.31 \\
\cline { 2 - 4 } & közepes mértékben (2.) & $\mathrm{H}=1.77+3.78^{*} \log (\mathrm{DBH})$ & 0.23 \\
\cline { 2 - 4 } & nagy mértékben (3.) & $\mathrm{H}=2.76+3.43^{*} \log (\mathrm{DBH})$ & 0.15 \\
\hline \multirow{4}{*}{$\begin{array}{c}\text { Acer } \\
\text { platanoides }\end{array}$} & nem fertözött (0.) & $\mathrm{H}=-6.52+6.22^{*} \log (\mathrm{DBH})$ & 0.51 \\
\cline { 2 - 4 } & kis mértékben (1.) & $\mathrm{H}=-1.83+4.49^{*} \log (\mathrm{DBH})$ & 0.36 \\
\cline { 2 - 4 } & közepes mértékben (2.) & $\mathrm{H}=15.33+0.76^{*} \log (\mathrm{DBH})$ & 0.01 \\
\cline { 2 - 4 } & nagy mértékben (3.) & $\mathrm{H}=13.36+1.27^{*} \log (\mathrm{DBH})$ & 0.01 \\
\hline \multirow{4}{*}{$\begin{array}{c}\text { Acer } \\
\text { pseudoplatanus }\end{array}$} & nem fertözött (0.) & $\mathrm{H}=-9.87+7.70^{*} \log (\mathrm{DBH})$ & 0.57 \\
\cline { 2 - 4 } & kis mértékben (1.) & $\mathrm{H}=-10.50+7.64^{*} \log (\mathrm{DBH})$ & 0.76 \\
\cline { 2 - 4 } & közepes mértékben (2.) & $\mathrm{H}=-4.48+5.76^{*} \log (\mathrm{DBH})$ & 0.21 \\
\cline { 2 - 4 } & nagy mértékben (3.) & $\mathrm{H}=25.90-1.67^{*} \log (\mathrm{DBH})$ & 0.02 \\
\hline
\end{tabular}




\begin{tabular}{|c|c|c|c|}
\hline Gazdafa & A fertőzés erőssége & Regressziós függvény & $\begin{array}{l}\text { Determinációs } \\
\text { együttható } \\
\left(\mathbf{R}^{2}\right)\end{array}$ \\
\hline \multirow{4}{*}{$\begin{array}{l}\text { Crataegus } \\
\text { spp. }\end{array}$} & nem fertőzött $(0)$. & $\mathrm{H}=1.60+1.95^{\star} \log (\mathrm{DBH})$ & 0.37 \\
\hline & kis mértékben (1.) & $H=1.01+2.33^{*} \log (\mathrm{DBH})$ & 0.35 \\
\hline & közepes mértékben (2.) & $\mathrm{H}=4.29+1.39^{*} \log (\mathrm{DBH})$ & 0.12 \\
\hline & nagy mértékben (3.) & $H=-4.60+4.16^{*} \log (\mathrm{DBH})$ & 0.68 \\
\hline \multirow{4}{*}{$\begin{array}{l}\text { Juglans } \\
\text { nigra }\end{array}$} & nem fertőzött $(0)$. & $\mathrm{H}=-14.53+8.57^{*} \log (\mathrm{DBH})$ & 0.60 \\
\hline & kis mértékben (1.) & $H=-5.02+5.74^{*} \log (\mathrm{DBH})$ & 0.17 \\
\hline & közepes mértékben (2.) & $\mathrm{H}=7.04+3.25^{\star} \log (\mathrm{DBH})$ & 0.06 \\
\hline & nagy mértékben (3.) & $\mathrm{H}=-18.01+9.61^{*} \log (\mathrm{DBH})$ & 0.19 \\
\hline \multirow{4}{*}{$\begin{array}{c}\text { Robinia } \\
\text { pseudoacacia }\end{array}$} & nem fertőzött $(0)$. & $H=-8.31+6.76^{*} \log (\mathrm{DBH})$ & 0.54 \\
\hline & kis mértékben (1.) & $H=-3.92+5.50^{*} \log (\mathrm{DBH})$ & 0.47 \\
\hline & közepes mértékben (2.) & $H=-3.52+5.99^{*} \log (\mathrm{DBH})$ & 0.32 \\
\hline & nagy mértékben (3.) & $H=-28.69+14.11^{*} \log (\mathrm{DBH})$ & 0.99 \\
\hline \multirow{4}{*}{$\begin{array}{c}\text { Tilia } \\
\text { cordata }\end{array}$} & nem fertőzött (0.) & $H=-8.66+6.76^{*} \log (\mathrm{DBH})$ & 0.46 \\
\hline & kis mértékben (1.) & $H=-0.31+4.30^{*} \log (\mathrm{DBH})$ & 0.19 \\
\hline & közepes mértékben (2.) & $H=-3.13+5.55^{*} \log (\mathrm{DBH})$ & 0.20 \\
\hline & nagy mértékben (3.) & $H=-8.05+7.13^{*} \log (\mathrm{DBH})$ & 0.32 \\
\hline \multirow{4}{*}{$\begin{array}{c}\text { Tilia } \\
\text { platyphyllos }\end{array}$} & nem fertőzött (0.) & $H=-9.86+7.52^{*} \log (\mathrm{DBH})$ & 0.51 \\
\hline & kis mértékben (1.) & $H=-11.75+8.52^{*} \log (\mathrm{DBH})$ & 0.48 \\
\hline & közepes mértékben (2.) & $H=-2.79+5.92^{*} \log (\mathrm{DBH})$ & 0.14 \\
\hline & nagy mértékben (3.) & $H=-15.0+8.27^{*} \log (\mathrm{DBH})$ & 0.14 \\
\hline
\end{tabular}

A 3. táblázat mutatja a részletes statisztikai próbák eredményeit a különböző regressziós koefficiensek esetében a gazdafajok, illetve a fagyöngyfertőzés függvényében. Kék színnel jelöltek azokat a paraméterek, amelyek statisztikailag magasan szignifikánsak, barnával pedig azok, amik csupán 5\%-os szignifikancia szinten szignifikánsak. Minden esetben feltüntettük a becsült paraméterek standard hibáját is.

A következő táblázatok mutatják a leíró statisztikát a famagasságra (4. táblázat), illetve a törzsátmérőre (5. táblázat) szintén a gazdafajok és fertőzés erősségének függvényében. Az átlagon kívül minden esetben feltüntettük a szórást, a móduszt, illetve a legkisebb és a legnagyobb értéket is. 
3. táblázat: A regressziós paraméterek alakulása különböző gazdafajok esetében a fagyöngyfertőzés függvényében.

Table 3: Development of regression coefficients with dependence of host taxa and mistletoe infection.

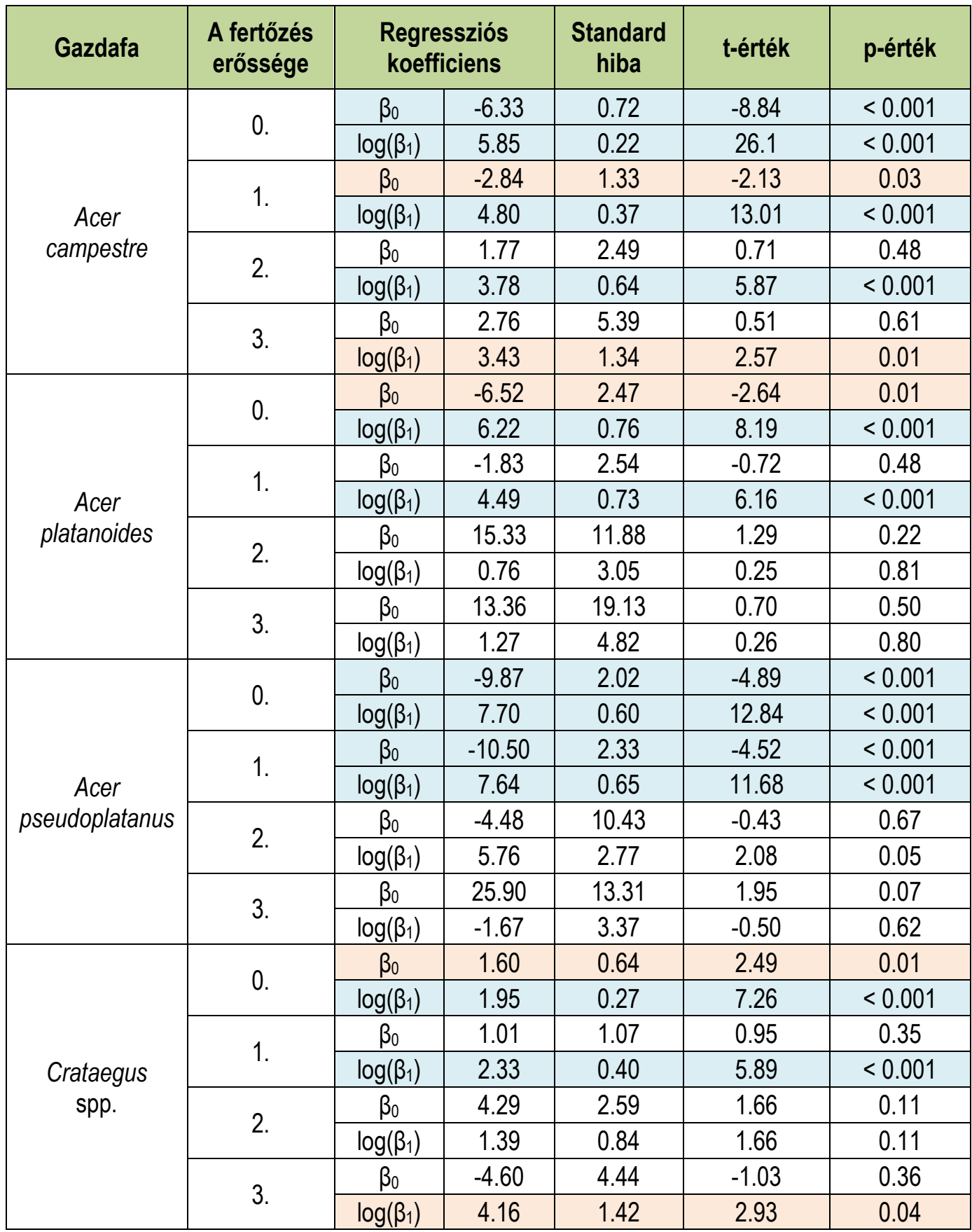




\begin{tabular}{|c|c|c|c|c|c|c|}
\hline Gazdafa & $\begin{array}{l}\text { A fertőzés } \\
\text { erössége }\end{array}$ & \multicolumn{2}{|c|}{$\begin{array}{l}\text { Regressziós } \\
\text { koefficiens }\end{array}$} & $\begin{array}{l}\text { Standard } \\
\text { hiba }\end{array}$ & t-érték & $\mathrm{p}$-érték \\
\hline \multirow{8}{*}{$\begin{array}{l}\text { Juglans } \\
\text { nigra }\end{array}$} & \multirow{2}{*}{0.} & $\beta_{0}$ & -14.53 & 4.19 & -3.47 & 0.002 \\
\hline & & $\log \left(\beta_{1}\right)$ & 8.57 & 1.24 & 6.88 & $<0.001$ \\
\hline & \multirow{2}{*}{1.} & $\beta_{0}$ & -5.02 & 10.10 & -0.50 & 0.63 \\
\hline & & $\log \left(\beta_{1}\right)$ & 5.74 & 3.23 & 1.78 & 0.10 \\
\hline & \multirow{2}{*}{2.} & $\beta_{0}$ & 7.04 & 8.27 & 0.85 & 0.40 \\
\hline & & $\log \left(\beta_{1}\right)$ & 3.25 & 2.24 & 1.45 & 0.16 \\
\hline & \multirow{2}{*}{3.} & $\beta_{0}$ & -18.01 & 14.88 & -1.21 & 0.24 \\
\hline & & $\log \left(\beta_{1}\right)$ & 9.61 & 3.70 & 2.60 & 0.01 \\
\hline \multirow{8}{*}{$\begin{array}{c}\text { Robinia } \\
\text { pseudoacacia }\end{array}$} & \multirow{2}{*}{0.} & $\beta_{0}$ & -8.31 & 2.69 & -3.09 & 0.003 \\
\hline & & $\log \left(\beta_{1}\right)$ & 6.76 & 0.79 & 8.53 & $<0.001$ \\
\hline & \multirow{2}{*}{1.} & $\beta_{0}$ & -3.92 & 2.44 & -1.60 & 0.11 \\
\hline & & $\log \left(\beta_{1}\right)$ & 5.50 & 0.73 & 7.55 & $<0.001$ \\
\hline & \multirow{2}{*}{2.} & $\beta_{0}$ & -3.52 & 13.95 & -0.25 & 0.81 \\
\hline & & $\log \left(\beta_{1}\right)$ & 5.99 & 3.59 & 1.67 & 0.15 \\
\hline & \multirow{2}{*}{3.} & $\beta_{0}$ & -28.69 & 2.77 & -10.34 & 0.06 \\
\hline & & $\log (\beta 1)$ & 14.11 & 0.88 & 15.96 & 0.04 \\
\hline \multirow{8}{*}{$\begin{array}{c}\text { Tilia } \\
\text { cordata }\end{array}$} & \multirow{2}{*}{0.} & $\beta_{0}$ & -8.66 & 1.53 & -5.66 & $<0.001$ \\
\hline & & $\log \left(\beta_{1}\right)$ & 6.76 & 0.49 & 13.72 & $<0.001$ \\
\hline & \multirow{2}{*}{1.} & $\beta_{0}$ & -0.31 & 3.19 & -0.10 & 0.92 \\
\hline & & $\log \left(\beta_{1}\right)$ & 4.30 & 0.92 & 4.66 & $<0.001$ \\
\hline & \multirow{2}{*}{2.} & $\beta_{0}$ & -3.13 & 4.56 & $\begin{array}{l}-0.69 \\
\end{array}$ & 0.49 \\
\hline & & $\log \left(\beta_{1}\right)$ & 5.55 & 1.17 & 4.77 & $<0.001$ \\
\hline & \multirow{2}{*}{3.} & $\beta_{0}$ & -8.05 & 4.16 & -1.94 & 0.06 \\
\hline & & $\log \left(\beta_{1}\right)$ & 7.13 & 1.02 & 6.99 & $<0.001$ \\
\hline \multirow{8}{*}{$\begin{array}{c}\text { Tilia } \\
\text { platyphyllos }\end{array}$} & \multirow{2}{*}{0.} & $\beta_{0}$ & -9.86 & 1.36 & -7.23 & $<0.001$ \\
\hline & & $\log \left(\beta_{1}\right)$ & 7.52 & 0.44 & 17.06 & $<0.001$ \\
\hline & \multirow{2}{*}{1.} & $\beta_{0}$ & -11.75 & 3.18 & -3.69 & $<0.001$ \\
\hline & & $\log \left(\beta_{1}\right)$ & 8.52 & 0.86 & 9.90 & $<0.001$ \\
\hline & \multirow{2}{*}{2.} & $\beta_{0}$ & -2.79 & 11.34 & -0.25 & 0.81 \\
\hline & & $\log \left(\beta_{1}\right)$ & 5.92 & 2.76 & 2.14 & 0.05 \\
\hline & \multirow{2}{*}{3.} & $\beta_{0}$ & -15.0 & 16.53 & -0.91 & 0.37 \\
\hline & & $\log \left(\beta_{1}\right)$ & 8.27 & 3.69 & 2.24 & 0.03 \\
\hline
\end{tabular}


4. táblázat: Leiró statisztikák a famagasságra a gazdafajok és a fertőzöttség függvényében.

Table 4: Descriptive statistics for tree height with dependence of infection and host taxa.

\begin{tabular}{|c|c|c|c|c|c|c|}
\hline Gazdafa & $\begin{array}{l}\text { A fertőzés } \\
\text { erőssége }\end{array}$ & $\begin{array}{l}\text { Átlag } \\
(\mathrm{m})\end{array}$ & $\begin{array}{l}\text { Szórás } \\
\text { (m) }\end{array}$ & $\begin{array}{l}\text { Módusz } \\
(\mathrm{m})\end{array}$ & $\begin{array}{c}\text { Legkisebb } \\
\text { érték (m) }\end{array}$ & $\begin{array}{l}\text { Legnagyobb } \\
\text { érték }(m)\end{array}$ \\
\hline \multirow{4}{*}{$\begin{array}{c}\text { Acer } \\
\text { campestre }\end{array}$} & 0. & 12.1 & 4.63 & 12 & 2 & 26 \\
\hline & 1. & 14.3 & 4.27 & 14 & 5 & 27 \\
\hline & 2. & 16.3 & 3.93 & 18 & 6 & 26 \\
\hline & 3. & 16.5 & 3.99 & 20 & 8 & 26 \\
\hline \multirow{4}{*}{$\begin{array}{c}\text { Acer } \\
\text { platanoides }\end{array}$} & 0. & 13.3 & 5.22 & 9 & 5 & 26 \\
\hline & 1. & 13.6 & 4.11 & 13 & 6 & 23 \\
\hline & 2. & 18.3 & 3.87 & 22 & 12 & 24 \\
\hline & 3. & 18.4 & 4.78 & 12 & 12 & 28 \\
\hline \multirow{4}{*}{$\begin{array}{c}\text { Acer } \\
\text { pseudoplata- } \\
\text { nus }\end{array}$} & 0. & 15.7 & 5.83 & 12 & 3 & 30 \\
\hline & 1. & 16.3 & 5.44 & 19 & 6 & 25 \\
\hline & 2. & 17.1 & 5.40 & 20 & 8 & 24 \\
\hline & 3. & 19.3 & 3.33 & 23 & 13 & 23 \\
\hline \multirow{4}{*}{$\begin{array}{l}\text { Crataegus } \\
\text { spp. }\end{array}$} & 0. & 6.1 & 1.85 & 6 & 2 & 13 \\
\hline & 1. & 7.2 & 1.95 & 7 & 4 & 12 \\
\hline & 2. & 8.5 & 2.29 & 10 & 5 & 13 \\
\hline & 3. & 8.3 & 2.16 & 11 & 6 & 11 \\
\hline \multirow{4}{*}{$\begin{array}{l}\text { Juglans } \\
\text { nigra }\end{array}$} & 0. & 13.6 & 8.40 & 7 & 3 & 31 \\
\hline & 1. & 12.8 & 5.07 & 9 & 7 & 25 \\
\hline & 2. & 18.9 & 5.22 & 20 & 7 & 28 \\
\hline & 3. & 20.5 & 6.24 & 15 & 11 & 33 \\
\hline \multirow{4}{*}{$\begin{array}{c}\text { Robinia } \\
\text { pseudoacacia }\end{array}$} & 0. & 14.1 & 6.63 & 9 & 4 & 28 \\
\hline & 1. & 14.1 & 5.75 & 12 & 4 & 26 \\
\hline & 2. & 19.6 & 5.40 & 20 & 11 & 27 \\
\hline & 3. & 15.0 & 8.72 & 11 & 9 & 25 \\
\hline \multirow{4}{*}{$\begin{array}{c}\text { Tilia } \\
\text { cordata }\end{array}$} & 0. & 12.0 & 5.83 & 12 & 3 & 32 \\
\hline & 1. & 14.4 & 4.50 & 10 & 5 & 27 \\
\hline & 2. & 18.5 & 5.39 & 22 & 8 & 35 \\
\hline & 3. & 20.8 & 5.67 & 20 & 7 & 35 \\
\hline \multirow{4}{*}{$\begin{array}{c}\text { Tilia } \\
\text { platyphyllos }\end{array}$} & 0. & 13.1 & 5.73 & 10 & 1.5 & 31 \\
\hline & 1. & 19.5 & 5.99 & 20 & 7 & 30 \\
\hline & 2. & 21.4 & 6.92 & 28 & 8 & 34 \\
\hline & 3. & 21.9 & 8.51 & 15 & 7 & 42 \\
\hline
\end{tabular}


5. táblázat: Leíró statisztikák a törzsvastagságra a gazdafajok és a fertőzöttség függvényében.

Table 5: Descriptive statistics for diameter at breast height with dependence of infection and host taxa.

\begin{tabular}{|c|c|c|c|c|c|c|}
\hline Gazdafa & $\begin{array}{l}\text { A fertőzés } \\
\text { erőssége }\end{array}$ & $\begin{array}{l}\text { Átlag } \\
(\mathrm{cm})\end{array}$ & $\begin{array}{l}\text { Szórás } \\
(\mathrm{cm})\end{array}$ & $\begin{array}{l}\text { Módusz } \\
\text { (cm) }\end{array}$ & $\begin{array}{l}\text { Legkisebb } \\
\text { érték (cm) }\end{array}$ & $\begin{array}{l}\text { Legnagyobb } \\
\text { érték }(\mathrm{cm})\end{array}$ \\
\hline \multirow{4}{*}{$\begin{array}{c}\text { Acer } \\
\text { campestre }\end{array}$} & 0. & 27.1 & 16.12 & 20 & 3 & 120 \\
\hline & 1. & 40.3 & 19.79 & 25 & 8 & 120 \\
\hline & 2. & 51.2 & 22.20 & 45 & 3 & 125 \\
\hline & 3. & 59.3 & 21.17 & 50 & 12 & 100 \\
\hline \multirow{4}{*}{$\begin{array}{c}\text { Acer } \\
\text { platanoides }\end{array}$} & 0. & 29.1 & 18.21 & 10 & 7 & 86 \\
\hline & 1. & 36.2 & 19.37 & 24 & 9 & 97 \\
\hline & 2. & 51.2 & 19.10 & 46 & 24 & 100 \\
\hline & 3. & 54.6 & 17.65 & 48 & 28 & 90 \\
\hline \multirow{4}{*}{$\begin{array}{c}\text { Acer } \\
\text { pseudoplata- } \\
\text { nus }\end{array}$} & 0. & 32.1 & 17.79 & 20 & 3 & 98 \\
\hline & 1. & 39.4 & 22.40 & 20 & 10 & 98 \\
\hline & 2. & 46.2 & 20.93 & 37 & 15 & 110 \\
\hline & 3. & 53.2 & 13.70 & 55 & 33 & 85 \\
\hline \multirow{4}{*}{$\begin{array}{l}\text { Crataegus } \\
\text { spp. }\end{array}$} & 0. & 11.8 & 6.55 & 10 & 2 & 40 \\
\hline & 1. & 15.9 & 7.77 & 8 & 4 & 42 \\
\hline & 2. & 23.6 & 9.76 & 28 & 3 & 44 \\
\hline & 3. & 24.3 & 11.17 & 15 & 15 & 43 \\
\hline \multirow{4}{*}{$\begin{array}{c}\text { Juglans } \\
\text { nigra }\end{array}$} & 0. & 34.9 & 25.22 & 60 & 10 & 96 \\
\hline & 1. & 23.6 & 7.29 & 25 & 9 & 37 \\
\hline & 2. & 42.3 & 17.91 & 35 & 13 & 100 \\
\hline & 3. & 57.5 & 19.59 & 40 & 35 & 125 \\
\hline \multirow{4}{*}{$\begin{array}{c}\text { Robinia } \\
\text { pseudoacacia }\end{array}$} & 0. & 34.7 & 23.21 & 15 & 4 & 106 \\
\hline & 1. & 34.4 & 27.54 & 15 & 7 & 130 \\
\hline & 2. & 53.2 & 26.98 & 32 & 25 & 91 \\
\hline & 3. & 25.3 & 17.04 & 16 & 15 & 45 \\
\hline \multirow{4}{*}{$\begin{array}{c}\text { Tilia } \\
\text { cordata }\end{array}$} & 0. & 25.1 & 15.86 & 15 & 6 & 95 \\
\hline & 1. & 34.4 & 16.97 & 35 & 10 & 91 \\
\hline & 2. & 53.2 & 21.65 & 45 & 10 & 120 \\
\hline & 3. & 62.9 & 27.67 & 65 & 16 & 200 \\
\hline \multirow{4}{*}{$\begin{array}{c}\text { Tilia } \\
\text { platyphyllos }\end{array}$} & 0. & 24.6 & 15.68 & 20 & 5 & 131 \\
\hline & 1. & 43.8 & 21.92 & 40 & 14 & 120 \\
\hline & 2. & 65.2 & 26.77 & 50 & 23 & 140 \\
\hline & 3. & 92.5 & 31.48 & 100 & 34 & 150 \\
\hline
\end{tabular}



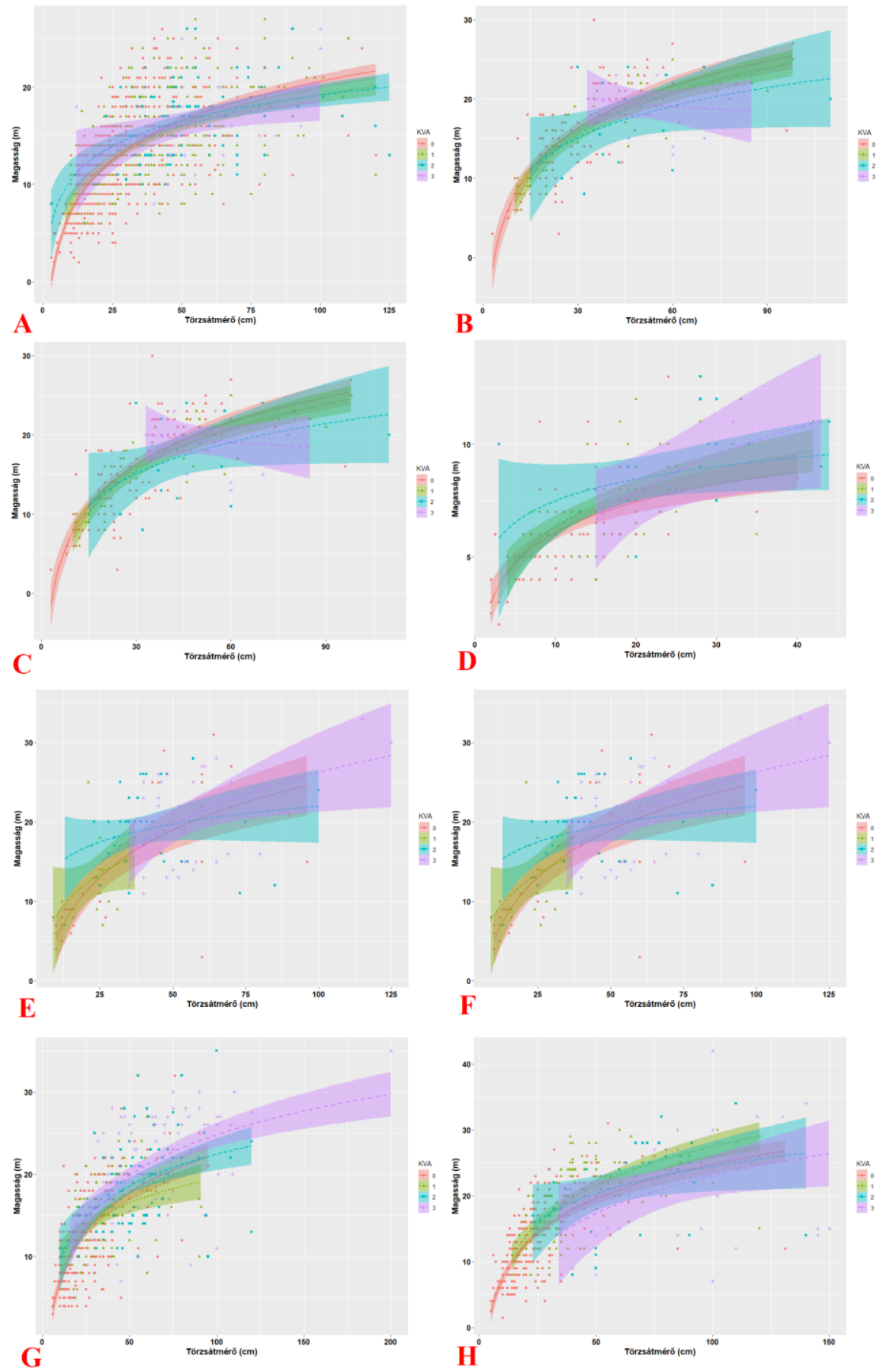

1. ábra: A famagasság és a törzsátmérő közötti kapcsolat vizsgálata a gazdafajok és a fertőzés erősségének függvényében.

Figure 1: Development of the relationship between tree height and diameter at breast height with dependence of host taxa and infection intensity. 
Az 1. ábra grafikusan mutatja a famagasság és a törzsátmérő közötti kapcsolatot a fertőzés erősségének függvényében. Egy ábra egy gazdafaj adatait ábrázolja ( $A$ - Acer campestre, B - Acer platanoides, C - Acer pseudoplatanus, D - Crataegus spp., E - Juglans nigra, F - Robinia pseudoacacia, G - Tilia cordata és H - Tilia platyphyllos), az ábrán belül a különböző színek eltérő fertőzöttséget jelölnek. A regressziós vonalon kívül feltüntettük a becsült értékek $95 \%$-os konfidencia intervallumát is (halványabb színnel jelölve). Az ábrából jól látható, hogy a fertőzés erősségével nemcsak a famagasság és a törzsátmérő közötti kapcsolat szorossága csökken (szélesebb a konfidencia intervallum), hanem a logaritmikus regressziós vonalak iránya is.

A kutatásunk eredményei egyértelműen megerősítették, hogy a fehér fagyöngy által okozott fertőzöttség statisztikailag szignifikánsan befolyásolja a famagasság és a törzsátmérő közötti kapcsolatot. A nem fertőzött egyedek esetében egyértelműen megfigyelhető a viszonylag erős kapcsolat a famagasság és a törzsátmérő között (a determinációs együttható értéke rendszerint $50 \%$ felett van), addig ez a kapcsolat a fertőzés intenzitásával fokozatosan csökken vagy teljesen megszünik. Ez a trend a gazdafajok többségénél megfigyelhetö. Mindazonáltal nem elhanyagolható az a szempont sem, hogy a vizsgált egyedek száma gazdafajonként erősen változó ( $p l$. a Juglans nigra faegyedek csak a 10\%-t teszik ki az Acer campestre faegyedeinek), ami az erősen fertőzött faegyedek esetén még nagyobb. Ebböl kifolyólag némely eredmény (pl. a determinációs együttható 99\%-os értéke a Robinia pseudoacacia erősen fertőzött egyedei esetében) már megtévesztő lehet.

A gyenge kapcsolat a fertőzött faegyedek esetében egyértelmüen utal a fagyöngy káros hatására, miszerint csökkenti az általa fertőzött gazdafaj magasságát. Az egyes gazdafajok eltérően reagálnak a fertőzésre, némelyik jobban (pl. Juglans nigra, Malus domestica stb.), míg mások kevésbé érzékenyek (pl. Pyrus pyraster, Quercus palustris stb.), ezért a famagasság és a törzsátmérő közötti kapcsolat modellezése korántsem olyan egyszerü, mint egészséges fák esetében. A gyenge kapcsolatot a magasság és a törzsátmérő között okozhatja az idő elötti megváltozott famagasság, illetve egyéb koronadeformáció is, ami egyrészt bekövetkezhetett a fagyöngy kárositása következtében (pl. az erősen fertőzött vázágak szárazabbak és könnyen törnek), de egyéb tényezők is ugyanolyan károsan hatnak (pl. a faállományban az erős növekedésü faegyed árnyékoló hatásával elnyomja a gyengébb növekedésüt stb.), ami a megfelelő statisztikai modellezést tovább nehezíti.

A fertőzött fák dendrometriai tulajdonságainak modellezése további nehézségekbe ütközik, mivel az adott faegyedröl rendszerint nem derül ki, hogy mióta fertőzött. Szintén nehéz megállapítani - még gazdafajon belül is - azt a fagyöngymennyiséget a lombkoronában, ami egyértelmüen károsan hat a fertőzött faegyed növekedésére. Ebböl kifolyólag az ilyen dendrometriai vizsgálatok eredményeit nagyobb körültekintéssel kell kiértékelni az esetleges hibás következtetések elkerülése miatt.

Abban az esetben, ha a gazdafa dendrometriai tulajdonságait szeretnék modellezni a fertőzés függvényében, célszerü az általunk alkalmazott módon becsülni a fertőzés erősségét (vagyis az összfagyöngytérfogatot viszonyítjuk a lombkorona térfogatához, amit érték- 
skálára konvertálunk át), mert egyéb módszerek (pl. a fertőzés meghatározása a fagyöngybokrok pontos mennyisége alapján) pontatlanabb képet adhatnak a fertőzésről (pl. azonos mennyiségü fagyöngybokor kisebb fertőzést jelenthet magas gazdafa, illetve nagyobb fertőzést kisebb faegyed esetében).

A famagasság és a törzsátmérő közötti kapcsolat vizsgálatához érdemes olyan statisztikai modellt választani, ami segítségével könnyen leírható e kapcsolat, ám a választott matematikai modell nem lehet túl bonyolult sem, mert akkor nehezebb a regressziós paraméterek értelmezése. Annak ellenére, hogy a magasság és törzsátmérő közötti kapcsolat nem lineáris, különböző transzformációk (leggyakrabban logaritmus) segítségével e kapcsolat lineárissá tehető és az elemzés könnyebben elvégezhető. A legtöbb esetben a törzsmagasság logaritmusa és a famagasság közötti kapcsolat már lineáris, azonban nem zárható ki az a lehetőség sem, hogy más matematikai modellel e kapcsolat jobban leírható. Bonyolultabb matematikai modell választása föleg abban az esetben indokolt, ha nagyon sok kiinduló adattal dolgozunk és lehetőség van részletes és mélyreható elemzést csinálni.

\section{ÖSSZEFOGLALÁS}

A famagasság és a törzsátmérő közötti kapcsolat matematikai modellezése rendkívül időigényes és összetett feladat föleg akkor, ha egyéb tényezők hatását is együttesen vizsgáljuk (pl. a fagyöngyfertőzés erössége). Az elemzés során elöször a dendrometriai tulajdonságok közötti kapcsolatra helyezzük a fö hangsúlyt, aztán következik a matematikai modell bővitésére a különböző vizsgált tényezők függvényében. A fagyöngybokrok jelenlétének hatását vizsgálni különösen nehéz, mivel egyrészt a gazdafajok eltérően reagálnak a fertözésre, másrészt a gazdafajok közötti (de akár gazdafajon belüli) eltérések is megnehezíthetik a vizsgálatot. Megjegyezendő, hogy a fertőzött fák esetében még a jól kiválasztott matematikai modell sem biztos, hogy jól illusztrálja a két dendrometriai tulajdonság közötti kapcsolatot (még magas determinációs együttható esetén sem), mivel a fagyöngy okozta károk (pl. koronadeformáció) jelentősen torzíthatja az eredményt. Ebből kifolyólag az alkalmazott statisztikai modell gyakorlati alkalmazása nehézségekbe ütközik és a fertőzött fák esetében nem, vagy csak nagyon körültekintően használhatók fel a famagasság modellezésre a törzsátmérő ismeretében. Természetesen e dendrometriai kapcsolat jellemzése alkalmazhatók egyéb lineáris vagy nem lineáris statisztikai modellek is (pl. lokális regresszió - Locally Weighted Linear Regression/LOESS) amik pontosabb eredményt is adhatnak, illetve a fagyöngy hatása is elemezhetö kevert modellek (Mixed effect models) segítségével, ami e tényezőt, mint véletlen (random) faktort veszi figyelembe. Az adatrendezés során kimondottan ügyelni kell, hogy ne keveredjenek össze a városi környezetben élő faegyedek fakataszteri adatai a természetes környezetben (pl. park, erdő stb.) előforduló faegyedeinek adataival, mivel a városi környezetben élök eleve nagyobb stressznek vannak kitéve, ami kihat a növekedési erélyre, ebböl kifolyólag a famagasság és a törzsátmérő közötti kapcsolat is különbözhet a normál körülményekre jellemzö matematikai modelltól. 


\section{FELHASZNÁLT IRODALOM}

Ahmadi K., Alavi S.J., Kouchaksarei M.T. \& Aertsen W. 2013: Non-linear height-diameter models for oriental beech (Fagus orientalis Lipsky) in the Hyrcanian forests, Iran. Biotechnology, Agronomy and Society and Environment 17(3): 431-440.

Barbu C.O. 2012: Impact of White mistletoe (Viscum album ssp. abietis) infection on needles and crown morphology of silver fir (Abies alba Mill.). Notulae Botanicae Horti Agrobotanici 40(2): 152-158. DOI: 10.15835/nbha4027906

Botkin D.B., Jamak J.F. \& Wallis J.R. 1972: Some ecological consequences of a computer model of forest growth. Journal of Ecology 60(3): 849-873. DOI: 10.2307/2258570

Buliř P. 2010: Analýza výskytu jmelí bílého (Viscum album L. ssp. album) a zdravotní stav dřevin v zámeckém parku Lednice. In: Vliv abiotických a biotických stresorů na vlastnosti rostlin 2010. Česká zemědělská univerzita v Praze, Praha, 160-163.

Calama R. \& Montero G. 2004: Interregional nonlinear height-diameter model with random coefficients for stone pine in Spain. Canadian Journal of Forest Research 34(1): 150-163. DOI: 10.1139/x03-199

Catal Y. \& Carus S. 2011: Effect of pine mistletoe on radial growth of crimean pine (Pinus nigra) in Turkey. Journal of Environmental Biology 32(3): 263-270.

Colbert K.C., Larsen D.R. \& Lootens J.R. 2002: Height-diameter equations for thirteen Midwestern bottomland hardwood species. Northern Journal of Applied Forestry 19(4): 171-176. DOI: 10.1093/njaf/19.4.171

Culek M. (ed): 1996: Biogeografické členění České republiky (Biogeographical division of the Czech Republic). Enigma, Praha, 347.

Curtis R.O., Clendenen G.W. \& Demars D.J. 1981: A new stand simulator for coast Douglas-fir DFSIM user's guide. U.S.D.A. Forest Service general technical report PNW (USA). no. 128. Pacific Northwest Forest and Range Experiment Station, Portland, Oregon.

Dobbertin M., Hilker N., Rebetez M., Zimmermann N.E., Wohlgemuth T. \& Rigling A. 2005: The upward shift in altitude of pine mistletoe (Viscum album ssp. austriacum) in Switzerland - the result of climate warming? International Journal of Biometeorology 50(1): 40-47. DOI: 10.1007/s00484-005-0263-5

Dobbertin M. \& Rigling A. 2006: Pine mistletoe (Viscum album ssp. austriacum) contributes to Scots pine (Pinus sylvestris) in the Rhole Valley of Switzerland. Forest Pathology 36(5): 309-322. DOI: 10.1111/j.14390329.2006.00457.x

Erhardt W. \& Zander R. 2008: Der große Zander: Enzyklopädie der Pflanzennamen. Vol. 2. Ulmer, Stuttgart, 2103.

Grundmann B.M., Pietzarka U. \& Roloff A. 2012: Die Weissbeerige Mistel (Viscum album L.): Biologie, Ökologie, Verwendung und Befallsrisiken. Mitteilungen der Deutschen Dendrologischen Gesellschaft 97: 75-90.

Hawksworth F.G. 1983: Mistletoes as forest parasites. In: Calder M. \& Bernhardt P. (eds): The biology of mistletoes, Academic Press, Sydney, 317-333.

Huang S. 1999: Ecoregion-based individual tree height-diameter models for lodgepole pine in Alberta. Western Journal of Applied Forestry 14(4): 186-193. DOI: 10.1093/wjaf/14.4.186

Huang S., Price D. \& Titus S.J. 2000: Development of ecoregion-based height-diameter models for white spruce in boreal forests. Forest Ecology and Management 129(1-3): 125-141. DOI: 10.1016/S03781127(99)00151-6

Huang S. \& Titus S.J. 1994: An age-independent individual tree height prediction model for boreal spruceaspen stands in Alberta. Canadian Journal of Forest Research 24(7): 1295-1301. DOI: 10.1139/x94-169

Kanat M., Alma M.H. \& Sivrikaya F. 2010: The effect of Viscum album L. on annual diameter increment of Pinus nigra Arn. African Journal of Agricultural Research 5(2): 166-171. DOI: 10.5897/AJAR09.482

Kartoolinejad D., Hosseini S.M., Mirnia S.K., Akbarinia M. \& Shayanmehr F. 2007: The relationship among infection intensity of Viscum album with some ecological parameters of host trees. International Journal of Environmental Research 1(2): 143-149. 
Kołodziejek J. \& Kołodziejek A. 2013: The spatial distribution of pine mistletoe Viscum album ssp. austriacum (Wiesb.) Volmann in a scots pine (Pinus sylvestris L.) stand in central Poland. Polish Journal of Ecology 61(4): 705-714.

Kołodziejek J., Patykowski J. \& Kołodziejek R. 2013: Distribution, frequency and host patterns of European mistletoe (Viscum album subsp. album) in the major city of Lodz, Poland. Biologia 68(1): 55-64. DOI: 10.2478/s11756-012-0128-4

Krejčirík P., Pejchal M., Šimek P., Buliř P. \& Pavlačka R. 2015: Dřeviny zámeckého parku v Lednici. Vydání první, Mendelova univerzita v Brně, Brno.

Krisnawati H., Wang Y. \& Ades P.K. 2010: Generalized height-diameter model for Acacia mangium Willd. plantations in South Sumatra. Indonesian Journal of Forestry Research 7(1): 1-19. DOI: 10.20886/ijfr.2010.7.1.1-19

Kurz W.A., Apps M.J., Webb T.M. \& McNamee P.J. 1992: The carbon budget of the Canadian forest sector: phase 1. Information Report NOR-X-326. Forestry Canada, Northwest Region, Northern Forestry Centre, Edmonton, AB, Canada.

Lumbres R.I.C., Lee Y.J., Seo Y.O., Kim S.H., Choi J.K. \& Lee W.K. 2011: Development and validation of nonlinear height-DBH models for major coniferous tree species in Korea. Forest Science and Technology 7(3): 117-125. DOI: 10.1080/21580103.2011.594610

Machovec J. 1982: Sadovnická dendrologie. SPN, Praha.

Misir N. 2010: Generalized height-diameter models for Populus tremula L. stand. African Journal of Biotechnology 9(28): 4348-4355.

Moore J.A., Zhang L. \& Stuck D. 1996: Height-diameter equations for ten tree species in the Inland Northwest. Western Journal of Applied Forestry 11(4): 132-137. DOI: 10.1093/wjaf/11.4.132

Niklas K.J. 1995: Size-dependent allometry of tree height, diameter and trunk-taper. Annals of Botany 75(3): 217-227. DOI: $10.1006 / a n b o .1995 .1015$

Noetzli K.Ph., Müller B. \& Sieber T.N. 2003: Impact of population dynamics of white mistletoe (Viscum album ssp. abietis) on European silver fir (Abies alba). Annals of Forest Science 60(8): 773-779. DOI: 10.1051/forest:2003072

Paganová V. 2008: Ecological requirements of wild service tree (Sorbus torminalis [L.] CRANTZ.) and service tree (Sorbus domestica L.) in relation with their utilization in forestry and landscape. Journal of Forest Science 54(5): 216-226. DOI: 10.17221/7/2008-JFS

Paganová V. \& Bakay L. 2010: Biologické vlastnosti jarabiny oskorušovej Sorbus domestica L. v meniacich sa podmienkach prostredia: vedecká monografia. 1. vyd. Slovenská pol'nohospodárska univerzita v Nitre, Nitra.

Pejchal M. 2008: Arboristika I.: obecná dendrologie. 1. vyd. Vyšší odborná škola zahradnická a střední zahradnická škola Mělník, Mělník.

Pejchal M. \& Šimek P. 1996: Vyhodnocení dendrologického potenciálu v zámeckém parku v Lednici na Moravě. Mendelova zemědělská a lesnická univerzita v Brně, Lednice na Moravě.

Peng C., Zhang L. \& Liu J. 2001: Developing and validating nonlinear height-diameter models for major tree species of Ontario's boreal forests. Northern Journal of Applied Forestry 18(3): 87-94. DOI: 10.1093/njaf/18.3.87

Procházka F. 2004: A centre of occurrence of Viscum album subsp. album in eastern Bohemia and an overview of the diversity of its host plants in Czech Republic. Preslia 76(4): 349-359.

Sharma R.P. 2009: Modelling height-diameter relationship for Chir pine trees. Banko Janakari 19(2): 3-9. DOI: 10.3126/banko.v19i2.2978

Sharma M. \& Zhang S.Y. 2004: Height-diameter models using stand characteristics for Pinus banksiana and Picea mariana. Scandinavian Journal of Forest Research 19(5): 442-451. DOI: 10.1080/02827580410030163

Skalický V. 1988: Regionálně fytogeografické členění (Regional-phytogeographical division). In: Hejný S. \& Slavík B. (eds): Květena České socialistické republiky 1. Academia, Praha, 103-121. 
Spálavský M. 2001: Zhodnocení rodu Viscum L. z pohledu zahradní a krajinářské tvorby. Diplomová práca, Mendelu v Brně, Zahradnická fakulta, Lednice.

Stopp F. 1961: Unsere Misteln. Ziemsen Verlag, Wittenberg Lutherstadt.

Šimek P. et al. 2003: Projekt obnovy zámeckého parku v Lednici na Moravě - Návrhová část. Mendelova univerzita v Brně, Lednice.

Šimek P., Pejchal M., Kučera P. et al. 2009: Regenerace a obnova vegetačních prvků v Lednickém parku. Mendelova univerzita v Brně, Lednice.

Tubeuf C.V. 1923: Monographie der Mistel. Verlag Oldenbourg, München. DOI: 10.5962/bhl.title.15456

Vanclay J.K. 1994: Modelling forest growth and yield: applications to mixed tropical forest. CAB International, Wallingford UK.

Wickham H. 2016: ggplot2: Elegant Graphics for Data Analysis. Springer-Verlag, New York.

Zhang L. 1997: Cross-validation of non-linear growth functions for modeling tree height-diameter relationships. Annals of Botany 79(3): 251-257. DOI: 10.1006/anbo.1996.0334

Zuber D. 2004: Biological flora of Central Europe: Viscum album L. Flora 199(3): 181-203. DOI: 10.1078/0367$\underline{2530-00147}$

\section{ONLINE FORRÁSOK}

Beaujean A.A. 2012: BaylorEdPsych: R Package for Baylor University Educational Psychology Quantitative Courses. R package version 0.5. URL: http://CRAN.R-project.org/package=BaylorEdPsych

Faria J.C., Grosjean P. \& Jelihovschi E. 2013: Tinn-R - GUl/Editor for R language and environment statistical computing. URL: http://sourceforge.net/projects/tinn-r

Pejchal M. \& Šimek P. 2015: Metodika hodnocení dřevin pro potřeby památkové péče. Certifikovaná metodika, Mendelova univerzita v Brně, Lednice. URL: http://www.nusl.cz/ntk/nusl-203604

R Core Team 2019: R: A language and environment for statistical computing. R Foundation for Statistical Computing, Vienna, Austria. URL: http://www.R-project.org/

RStudio Team 2015: RStudio: Integrated Development for R. RStudio, Inc., Boston, MA. URL: http://www.rstudio.com/

Érkezett: 2019. június 5.

Közlésre elfogadva: 2019. november 15. 